\title{
IN VITRO ANTIOXIDANT POTENTIAL AND HEPATOPROTECTIVE ACTIVITY OF TAXUS WALLICHIANA
}

\author{
MUZAFAR AHMAD BHAT ${ }^{1}$, SHOWKAT AHMAD GANIE ${ }^{2}$, KHALID BASHIR DAR ${ }^{2}$,ROHAYA ALI ${ }^{1}$, RABIA HAMID ${ }^{1}$
}

${ }^{1}$ Department of Biochemistry, University of Kashmir, Srinagar, Jammu and Kashmir, India. ${ }^{2}$ Department of Clinical Biochemistry, University of Kashmir, Srinagar, Jammu and Kashmir, India. Email: rabeyams@yahoo.co.in

Received: 02 September 2018, Revised and Accepted: 27 April 2018

\section{ABSTRACT}

Objectives: Taxus wallichiana, the member of family Taxaceae is used for the cure of various ailments by a large ethnic population native to the forests in Kashmir valley. The aim of this study is to evaluate antioxidant potential and hepatoprotective action of T. wallichiana as claimed by the ethnic population segment.

Methods: Antioxidant potential of different T. wallichiana extracts was evaluated by estimating the total phenolics, 1,1-diphenyl -2-picrylhydrazyl (DPPH), reducing power, microsomal lipid peroxidation (LPO), and hydroxyl radical scavenging activity through standard protocols. Hepatoprotective activity of T. wallichiana was determined by evaluation of liver marker enzyme (aspartate transaminase, alanine transaminase, and alkaline phosphatase) levels using standard protocols and by histological analysis of rat liver tissues of different animal groups against $\mathrm{CCl}_{4}$ induced liver damage.

Results: Phenolic content expressed as gallic acid equivalents (GAE/g) was found maximum in case of ethanolic extract (153.34 mg GAE/g), followed by extracts of methanol (149.24 mg GAE/g), hexane (134 mg GAE/g), ethyl acetate (128.9 mg GAE/g), chloroform (121.37 mg GAE/g), and aqueous (113.00 mg GAE/g). At concentration of $700 \mu \mathrm{g} / \mathrm{ml}$, DPPH radical scavenging activity of methanol extract was $88.29 \%$ with $\mathrm{IC}_{50}(212.00 \mu \mathrm{g} / \mathrm{ml}$ ), aqueous $(82.47 \%)$ with $\mathrm{IC}_{50}(258.29 \mu \mathrm{g} / \mathrm{ml})$, and ethyl acetate $(79.57 \%)$ with $\mathrm{IC}_{50}(301.80 \% \mu \mathrm{g} / \mathrm{ml})$. The reducing power of the extracts increased in a concentration dependent manner. At concentration of $700 \mu \mathrm{g} / \mathrm{ml}, 79 \%, 68 \%$, and $56 \%$ inhibition was observed with extracts of methanol, aqueous, and ethyl acetate on microsomal LPO with IC $_{50}$ values of $126.09,168.83$, and $151.96 \mu \mathrm{g} / \mathrm{ml}$, respectively. Superoxide radical scavenging activity of T. wallichiana extracts increased in a dose-dependent manner with $\mathrm{IC}_{50}$ values $170.30 \mu \mathrm{g} / \mathrm{ml}$ (methanol), $257.00 \mu \mathrm{g} / \mathrm{ml}(\mathrm{aqueous}$ ), and $297.55 \mu \mathrm{g} / \mathrm{ml}$ ethyl acetate extract. T. wallichiana extracts exhibited antioxidant effects on calf thymus DNA damage. The results further depict the hepatoprotective action of T. wallichiana extract at doses of 100 and $300 \mathrm{mg} / \mathrm{kg}$ and were comparable with that of standard treatment comprising $50 \mathrm{mg} / \mathrm{kg}$-day of Vitamin C, a known hepatoprotective agent. The data were substantiated with histopathological studies of rat liver sections.

Conclusion: These results comprehensively depict that T. wallichiana extracts are endowed with the free radical sequestering potential and be employed as potential antioxidant and hepatoprotective arsenal against many oxidative stress linked diseases.

Keywords: Taxus wallichiana, Radical scavenging, 1,1-Diphenyl -2-picrylhydrazyl, DNA protection, Hepatoprotective, Histopathology.

(C) 2018 The Authors. Published by Innovare Academic Sciences Pvt Ltd. This is an open access article under the CC BY license (http://creativecommons. org/licenses/by/4. 0/) DOI: http://dx.doi.org/10.22159/ajpcr.2018.v11i8.22345

\section{INTRODUCTION}

Taxus wallichiana is a member of family Taxaceae found in temperate Himalayas at an altitude of 1800-3300 $\mathrm{m}$ and geographically distributed in Europe, North America, North India, Pakistan, China, and Japan [1]. It is a medium-sized evergreen tree attaining a height of 10-28 m. Its leaves are flat, dark green, and spirally arranged [2]. In Asia, it is distributed along Afghanistan through the Himalayas to the Philippines and is widely found in India and Pakistan. The Himalayan yew has high ethnobotanical importance and medicinal value [3]. T. wallichiana has an incredible history of its usage in the traditional system of medicine. The native people living close to forests possess substantial degree of traditional acumen on plant utilization. Himalayan medicinal plants form important constituents of alternative medicinal systems such as Amchi, Ayurveda, Han Chinese, Unani, and other traditional medicine systems that are prevalent in this region. Existing literature on T. wallichiana shows its analgesic, antipyretic, anti-inflammatory, immunomodulatory, antiallergic, anticonvulsant, anticociceptive, antiosteoporotic, antibacterial, antifungal, antiplatelet, and antispasmodic activities, and vasorelaxing effect [2,4-7]. In India, its leaves and bark are used in Unani drug "Zarnab" prescribed as a sedative, aphrodisiac and as cure for bronchitis, asthma, epilepsy, snake bite, and scorpion stings [3]. Its leaves and bark are used in treating rheumatism and its extracts are used in hair oils. It is consumed as decoctions, herbal tea, and juice for treating cold, cough, respiratory infections, indigestion, and epilepsy. It is used locally on the infected wounds and burns $[6,8]$.

Biological oxidative stress caused due to reduced production of antioxidants in the body and the prominent elevation in the levels of oxidants/free radicals is implicated in varied human pathologies notably cancer, diabetes, inflammation, neurodegenerative diseases, and atherosclerosis diseases. Free radicals such as reactive oxygen species (ROS) and reactive nitrogen species have seriously damaging effects on biological macromolecules such as lipids, proteins, DNA, and carbohydrates that constitute the cellular components [9-13]. As a prominent example, free radicals damage liver leading to acute and chronic hepatic injury $[14,15]$. Hepatotoxic effect of carbon tetra chloride $\left(\mathrm{CCl}_{4}\right)$, a potent free radical is the result of its biotransformation to trichloromethyl free radical $\left(\mathrm{CCl}_{3}\right)$ or trichloroperoxyl radical $\left(\mathrm{CCl}_{3} \mathrm{O}_{2}\right)$ by the mixed-function cytochrome $\mathrm{P}_{450}$ oxygenase system of the endoplasmic reticulum that causes oxidative stress and membrane damage characterized by atrophy of parenchyma, necrosis and degeneration [16-19]. This study focuses on evaluating the potential of various extracts of $T$. Wallichiana to scavenge oxidants/free radicals such as hydroxyl radical, superoxide radical, and 1,1-diphenyl -2-picrylhydrazyl (DPPH); besides, determining their reducing power and ability to inhibit lipid peroxidation (LPO). 
In addition, the study also focuses on assessing the hepatoprotective action of T. wallichiana active extract(s) in Wistar rat model. Thus, this study will prove beneficial to testify the traditional therapeutic claims pertaining to T. wallichiana and provides the basis for the future research to use this medicinal plant as a source of effective drugs against oxidative stress related diseases.

\section{METHODS}

The leaves of T. wallichiana were collected from Gulmarg area of Jammu and Kashmir (India) during the month of July 2014, identified at the Centre of Plant Taxonomy (COPT), Department of Botany, University of Kashmir, and authenticated by Akhtar Hussain Malik (curator). A reference specimen has been retained in the herbarium under reference number 2380-KASH.

The identified plant material was shade dried under room temperature at $30 \pm 2^{\circ} \mathrm{C}$. The dried plant material was ground into powder using mortar and pestle and passed through a sieve of $0.3 \mathrm{~mm}$ aperture size. The powder obtained was successively extracted in different solvents using Soxhlet extractor $\left(60-80^{\circ} \mathrm{C}\right)$. The extracts were then concentrated with the help of rotary evaporator under reduced pressure and the solid extracts were stored under refrigeration for further use.

Phytochemical screening of the crude extracts

Phytochemical screening was performed using various standard procedures.

\section{Determination of total phenol content (TPC)}

The phenolic content was determined by Folin-Ciocalteu reagent method as described by McDonald et al. [20] with slight change. $0.5 \mathrm{ml}$ of extract was mixed with $0.1 \mathrm{ml}$ of Folin-Ciocalteu reagent $(0.5 \mathrm{~N})$ and incubated at room temperature for $5 \mathrm{~min}$. Then, $2.5 \mathrm{ml} \mathrm{Na}_{2} \mathrm{CO}_{3}$ solution was added and the mixture was incubated for $30 \mathrm{~min}$ before the absorbance was recorded at $760 \mathrm{~nm}$. The TPC is expressed in terms of gallic acid equivalents (GAE) (mg/g of extracted compound).

\section{DPPH free radical scavenging activity}

DPPH assay was performed using the modified method of Kim et al. [21]. The free radical formed from DPPH was allowed to react with 100-700 $\mu \mathrm{g} / \mathrm{ml}$ of the extracts and incubated for $30 \mathrm{~min}$ before absorbance was read at $517 \mathrm{~nm}$. The percentage inhibitory activity was calculated by the following formula:

\%Inhibition $=\left(\mathrm{A}_{0}\right)-\left(\mathrm{A}_{1}\right) \times 100$

Where $\left(A_{0}\right)$ is the absorbance without extract and $\left(A_{1}\right)$ is the absorbance with plant extract.

\section{Reducing power assay}

The assay was conducted according to the method of Oyaizu [22]. Various concentrations of T. wallichiana extract added to $2.5 \mathrm{ml}$ of $0.2 \mathrm{M}$ phosphate buffer ( $\mathrm{pH} \mathrm{6.6)}$, and $2.5 \mathrm{ml}$ of $1 \%$ potassium hexacyanoferrate $\left[\mathrm{K}_{3} \mathrm{Fe}(\mathrm{CN})_{6}\right]$. The reaction mixture was incubated for $20 \mathrm{~min}$ at $50^{\circ} \mathrm{C}$. Then, the reaction was stopped by adding $2.5 \mathrm{ml}$ of $10 \%$ trichloroacetic acid (TCA). The reaction mixture was centrifuged at $3000 \mathrm{rpm}$ for 10 $\min$ and the upper layer of the solution $(2.5 \mathrm{ml})$ collected, followed by the mixing with distilled water $(2.5 \mathrm{ml})$ and $\mathrm{FeCl}_{3}(0.5 \mathrm{ml}, 0.1 \%)$. The absorbance was measured at $700 \mathrm{~nm}$.

Reduction(\%)=[1-(1- $\left.\left.\mathrm{A}_{\mathrm{C}} / \mathrm{A}_{\mathrm{S}}\right)\right] \times 100$

Where, $\left(A_{C}\right)$ is absorbance of standard at maximum concentration tested and $\left(\mathrm{A}_{\mathrm{S}}\right)$ is absorbance of sample.

\section{Hydroxyl radical scavenging}

Hydroxyl free radical, resulting from Fenton reaction was determined by degradation of deoxyribose that results in formation of thiobarbituric acid reactive species (TBARS) [23]. Reaction mixture containing $25 \mathrm{mM}$ deoxyribose, $10 \mathrm{mM}$ Ferric chloride, $100 \mathrm{mM}$ ascorbic acid, $2.8 \mathrm{mM} \mathrm{H}_{2} \mathrm{O}_{2}$ in $10 \mathrm{mM} \mathrm{KH}_{2} \mathrm{PO}_{4}$ ( $\mathrm{pH}$ 7.4), and various concentrations of T. wallichiana extracts. The reaction mixture was incubated for $1 \mathrm{~h}$ at $37^{\circ} \mathrm{C}$, followed by addition of $1 \mathrm{ml}$ of $1 \%$ TBA and $1 \mathrm{ml}$ of 3\% TCA. Then heated the reaction mixture at $100^{\circ} \mathrm{C}$ for $20 \mathrm{~min}$ before measuring absorbance at $532 \mathrm{~nm}$. The results were expressed as percentage inhibition of deoxyribose oxidation.

\%Inhibition $=\left(\mathrm{A}_{\mathrm{C}}-\mathrm{A}_{\mathrm{O}} / \mathrm{A}_{\mathrm{C}}\right) \times 100$

Where $A_{C}$ is the absorbance in the presence of control and $A_{0}$ is the absorbance in the presence of the extract.

\section{Superoxide radical scavenging activity}

The assay based on the degree of competence of different extracts of T. Wallichiana to inhibit formazan formation through sequestering the superoxide radicals produced in Riboflavin-light-NBT system [24]. The reaction mixture contained $50 \mathrm{mM}$ phosphate buffer (pH7.6), $20 \mu \mathrm{g}$ riboflavin, $12 \mathrm{mM}$ EDTA, and NBT $0.1 \mathrm{mg} / 3 \mathrm{ml}$, supplemented in order. Started the reaction with illuminating the reaction mixture of various concentrations of extract/standard for $90 \mathrm{~s}$. Instantly after illumination, the absorbance was read at $590 \mathrm{~nm}$. Butylated hydroxytoluene (BHT) was used as positive control. The percentage inhibition calculated using the following equation:

\%Inhibition $=\left(1-\mathrm{A}_{\mathrm{S}} / \mathrm{A}_{\mathrm{C}}\right) \times 100$

Where $A c$ is the absorbance of the control and $A s$ is the absorbance in the presence of extracts.

\section{LPO assay}

The LPO assay was carried out by the method described earlier [25]. Liver microsomes were incubated for $5 \mathrm{~min}$ with and without of plant extracts $(50 \mu-300) \mu \mathrm{g}$. Then, $100 \mu \mathrm{M} \mathrm{FeSO}_{4}$ and $50 \mu \mathrm{M} \mathrm{H}_{2} \mathrm{O}_{2}$ were added and incubated in $0.15 \mathrm{M} \mathrm{NaCl}(\mathrm{pH} 7)$ for $20 \mathrm{~min}$ at $37^{\circ} \mathrm{C}$. Incubation for control was performed with blank received vehicle only and for induced with vehicle cum liver microsomes but devoid of plant extract. Reaction was stopped by adding TCA-TBA reagent $(5 \% \mathrm{w} / \mathrm{v})$ and the extent of LPO was determined as malondialdehyde (MDA) formed per mg of protein at $532 \mathrm{~nm}$ absorbance.

\%inhibition $=1-($ Induced - Treated $/$ Induced - Control $) \times 100$

\section{Hepatoprotective activity of T. wallichiana extracts}

In $\mathrm{CCl}_{4}$ treated rats, the biochemical parameters reflect the change in the levels of various liver enzymes markers (aspartate transaminase [AST], alanine transaminase [ALT], and alkaline phosphatase [ALP]) in serum directly referring to alterations in the hepatic structural integrity [26]. In this study, we have evaluated the hepatoprotective potential of methanolic extract of T. wallichiana against $\mathrm{CCl}_{4}$ intoxication. Animals were divided into five groups, each of six animals. The level of liver marker enzymes (ALT, AST, and ALP) of all groups of animals was evaluated. The result was substantiated with histopathological study of liver sections of different groups of Wistar rats.

\section{Experimental design}

Wistar rats weighing 200-230 g were divided into five groups, each group consisting of six animal $(\mathrm{n}=6)$. These groups were arranged in the following order:

Group I: Received olive oil vehicle only at $5 \mathrm{ml} / \mathrm{kg}$-day.

Group II: Received $\mathrm{CCl}_{4}$ in olive oil vehicle only.

Group III: Received Vitamin C (50 mg/kg-day).

Group IV: Received $1.0 \mathrm{ml}$ of plant extract ( $100 \mathrm{mg} / \mathrm{kg} /$ body wt) orally for 19 days.

Group V: Received $1.0 \mathrm{ml}$ of plant extract ( $300 \mathrm{mg} / \mathrm{kg} /$ body wt) orally for 19 days.

On the 19 days, animals from Groups II to $\mathrm{V}$ were injected intraperitoneally with $\mathrm{CCl}_{4}$ in olive oil vehicle at a dosage of $1 \mathrm{ml} / \mathrm{kg}$ body weight. The rats were sacrificed $48 \mathrm{~h}$ after $\mathrm{CCl}_{4}$ administration and before which blood samples were taken from retro-orbital 
plexus liver tissues were taken and preserved in 10\% methanol for histopathological analysis.

\section{Histopathological examination and grading}

After proper processing liver tissues of Wistar rats were embedded in paraffin using an embedding machine. Paraffin blocks were cut using a rotary ultramicrotome, spread onto glass slides and then dried overnight. Slides were monitored under a light microscope after being stained with hematoxylin and eosin dyes and mounted, and then histopathological grading was performed.

\section{Statistical analysis}

Determination of TPC, DPPH radical, superoxide radical, hydrogen peroxide, hydroxyl radical, and LPO assays was conducted in triplicates. The value for each sample was calculated as mean \pm standard deviation.

\section{RESULTS}

\section{Qualitative phytochemical investigation}

The results of qualitative phytochemical investigation of the crude extracts of T. wallichiana are shown in Table 1. In the methanol extract, maximum amount of flavonoids, terpenoids, and phenols were present. Cardiac glycosides and steroids were present in moderate amounts in methanolic and aqueous extract of the plant. Tannins and saponins were absent in all the extracts, although aqueous extract showed fairly good amount of saponins.

\section{Total phenolics}

Phenols being important antioxidants due to the presence of phenolic groups readily reduce the free radicals put hence stop to otherwise fast flowing cascade of reactions, which are etiologically implicated in many disorders.

Various crude extracts of the plant T. wallichiana were screened for phenolic content and it was found that highest phenolic content was recorded for methanolic extract of T. wallichiana (153.34 mg GAE/g), followed by methanolic extract (149.24 mg GAE/g), hexane (134.0 mg GAE/g), ethyl acetate (128.9 mg GAE/g), chloroform (121.37 mg GAE/g), and least was recorded for hexane (113.0 $\mathrm{mg} \mathrm{GAE} / \mathrm{g}$ ).

\section{DPPH radical scavenging activity of T. wallichiana extracts}

The DPPH radical scavenging method is the most reliable method for determining the antioxidant potential of extracts (Fig. 1). TPC manifest its trend strongly in DPPH radical scavenging assay. Seven concentrations $(100-700 \mu \mathrm{g} / \mathrm{ml})$ of plant extracts were evaluated and percentage inhibition was recorded in dose-dependent manner. The highest DPPH activity was observed in methanolic extract $(91.25 \%)$ followed by aqueous (87.64\%), ethanol (85.23\%), and ethyl acetate $(83.27 \%)$ at highest concentration $(700 \mu \mathrm{g} / \mathrm{ml})$, whereas BHT was used as standard showed $(94.62 \%)$ at the same concentration. The $\mathrm{IC}_{50}$ values of three extracts were recorded as $212.00,258.29$, and $301.80 \mu \mathrm{g} / \mathrm{ml}$, respectively, which was inversely related to the antioxidant capacity (Table 2).

\section{Reducing power}

The reducing power was increasing in a dose-dependent manner. As shown in Fig. 2, a higher absorbance value indicates a stronger reducing power of the samples. The reducing power activity of methanolic extract at $100-700 \mu \mathrm{g} / \mathrm{ml}$ was increased from $0.225 \mathrm{~nm}$ to $0.745 \mathrm{~nm}$, respectively. The reducing power activity of the aqueous and ethyl acetate extracts also increased in a concentration dependent manner. At the higher concentration of the extracts $(700 \mu \mathrm{g} / \mathrm{ml})$, we observed absorbance of $0.601 \mathrm{~nm}$ and $0.518 \mathrm{~nm}$, respectively.

\section{Superoxide radical scavenging activity of $T$. wallichiana extracts}

Superoxide radicals produced from riboflavin-light-NBT system can be measured by their ability to reduce NBT. The minimizing trend in absorbance at $590 \mathrm{~nm}$ in the presence of plant extracts and the reference standard BHT show their abilities to sequester superoxide radicals. Superoxide radical scavenging increased in concentration dependent manner (Fig. 3). At the higher concentration of the plant extract $(600 \mu \mathrm{g} / \mathrm{ml})$, we observed $83.50 \%, 75.62 \%$, and $71.01 \%$ inhibition with methanol, aqueous, and ethyl acetate extract, respectively. The IC values (Table 2) of the plant extracts on superoxide scavenging activity were $170.30 \mu \mathrm{g} / \mathrm{ml}, 257.00 \mu \mathrm{g} / \mathrm{ml}$, and $297.55 \mu \mathrm{g} / \mathrm{ml}$, respectively. BHT a known antioxidant showed $89.57 \%$ inhibition at the concentration of $600 \mu \mathrm{g} / \mathrm{ml}$.

\section{Microsomal LPO of $T$, wallichiana extracts}

The anti-LPO activity of different extracts of T. wallichiana was evaluated using rat liver microsomes. Addition of $\mathrm{FeSO}_{4}$ and $\mathrm{H}_{2} \mathrm{O}_{2}$ to the microsomal suspension increased TBARS. When the microsomes had been pre-treated with extracts, the production of TBARS was inhibited markedly in a dose-dependent manner. At concentrations $50-300 \mu \mathrm{g} / \mathrm{ml}$, the extracts exhibit different degrees of anti-LPO activity. The percentage inhibition for ethyl acetate extract ranges from $23 \%$ to $56 \%$ at the concentrations of $50-300 \mu \mathrm{g} / \mathrm{ml}$, aqueous extract inhibition rate was found to be $30-68 \%$ and for methanolic extract the percentage inhibition varies from $35 \%$ to $79 \%$ at the same concentrations, respectively (Fig. 4). The half inhibitory concentration $\left(\mathrm{IC}_{50}\right)$ of the extracts in this system was $126.09 \mu \mathrm{g} /$ $\mathrm{ml}$ (methanol), $168.83 \mu \mathrm{g} / \mathrm{ml}$ (aqueous extract), and $151.96 \mu \mathrm{g} / \mathrm{ml}$ with ethyl acetate extract (Table 2). BHT a known antioxidant used

Table 1: Phytochemical analysis of various extracts of $T$. wallichiana

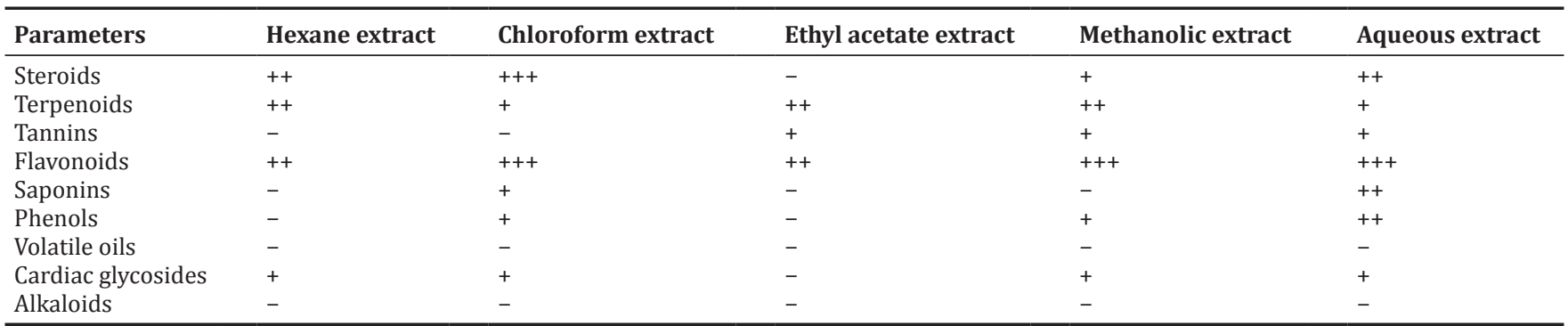

+: Present, -: Absent. T. wallichiana: Taxus wallichiana

Table 2: $\mathrm{IC}_{50}$ values $(\mu \mathrm{g} / \mathrm{ml})$ of $T$. wallichiana extracts

\begin{tabular}{lllll}
\hline Extracts & DPPH & Superoxide radical & LPO & Hydroxyl radical \\
\hline Methanolic & $212.00 \pm 2.29$ & $170.30 \pm 2.25$ & $126.09 \pm 3.07$ & $82.34 \pm 1.98$ \\
Aqueous & $258.29 \pm 3.24$ & $257.00 \pm 3.70$ & $168.83 \pm 2.67$ & $175.33 \pm 2.72$ \\
Ethyl acetate & $301.80 \pm 4.42$ & $297.55 \pm 4.12$ & $151.96 \pm 2.38$ & $199.05 \pm 3.65$ \\
\hline
\end{tabular}

The data were presented as means \pm SD of three parallel measures and evaluated by one-way ANOVA. SD: Standard deviation, DPPH: 1,1-diphenyl -2-picrylhydrazyl,

LPO: Lipid peroxidation, T. wallichiana: Taxus wallichiana 
Table 3: Effect of methanolic extract of $\mathrm{T}$. Wallichiana on biochemical parameters in $\mathrm{CCl}_{4}$ induced toxicity in Wistar rat model

\begin{tabular}{lll}
\hline Group & ALT IU/l & AST IU/L \\
\hline Normal & $23.55 \pm 3.4$ & $28.61 \pm 5.02$ \\
Positive Control & $129.42 \pm 10.76$ & $126.53 \pm 11.2$ \\
Vitamin C (50 mg/kg) & $60.40 \pm 2.10$ & $48.79 \pm 4.2$ \\
T. wallichiana extract (100 mg/kg) & $86.62 \pm 4.90$ & $91.63 \pm 5.7$ \\
T. wallichiana extract (300 mg/kg) & $69.55 \pm 5.20$ & $63.35 \pm 6.2$ \\
\hline
\end{tabular}

The data are presented as mean \pm SD for six animals $(n=6)$ in each observation and evaluated by one-way ANOVA followed by Bonferroni's t-test. ALT: Alanine transaminase, AST: Aspartate transaminase, LDH: Lactate dehydrogenase, SD: Standard deviation, T. wallichiana: Taxus wallichiana

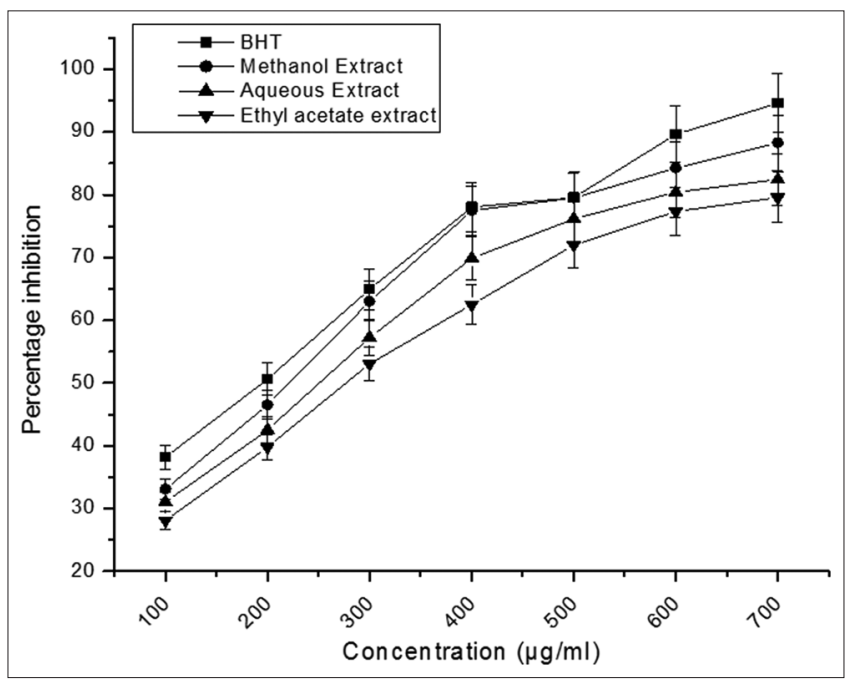

Fig. 1: Effect of different extracts of Taxus wallichiana and known antioxidant butylated hydroxytoluene on

1,1-diphenyl -2-picrylhydrazyl radical scavenging activity, measured at $517 \mathrm{~nm}$, with each result representing mean \pm standard deviation of 3 separate experiments

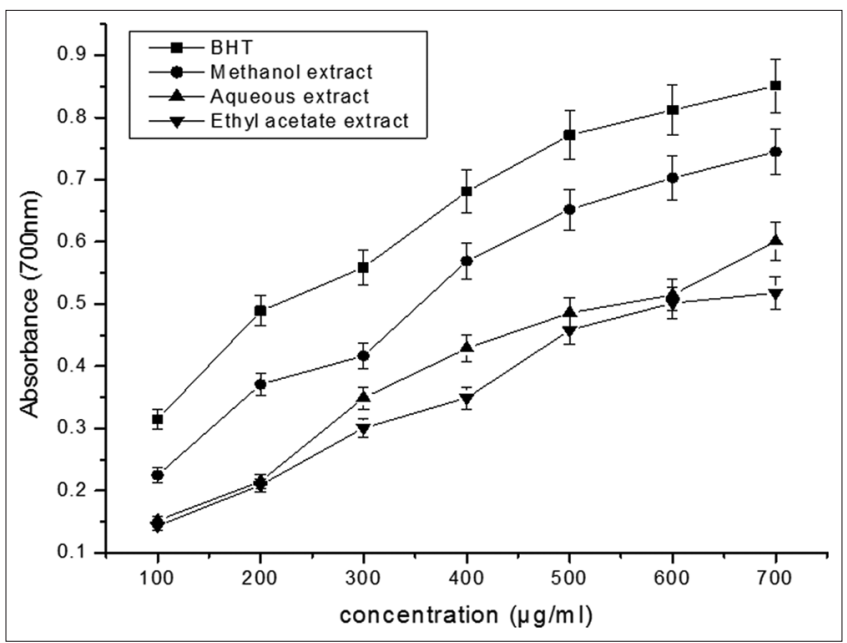

Fig. 2: The effect of different extracts of Taxus wallichiana and known antioxidant butylated hydroxytoluene on reducing power activity, measured at $700 \mathrm{~nm}$, with each result representing mean \pm standard deviation of 3 separate experiments

in the study inhibited the TBARS formation up to $88.00 \%$ at the concentration of $300 \mu \mathrm{g} / \mathrm{ml}$.

Hydroxyl radical scavenging activity of T. wallichiana extracts A significant decrease in concentration of hydroxyl radical was

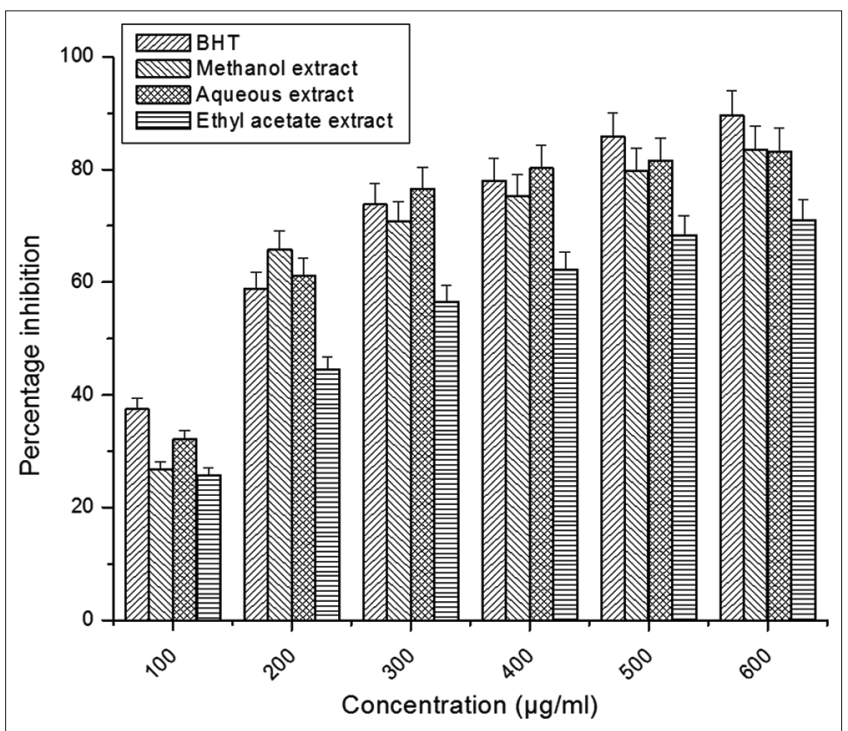

Fig. 3: The effect of different extracts of Taxus wallichiana and known antioxidant butylated hydroxytoluene on superoxide radical activity, measured at $590 \mathrm{~nm}$, with each result representing mean \pm standard deviation of 3 separate experiments

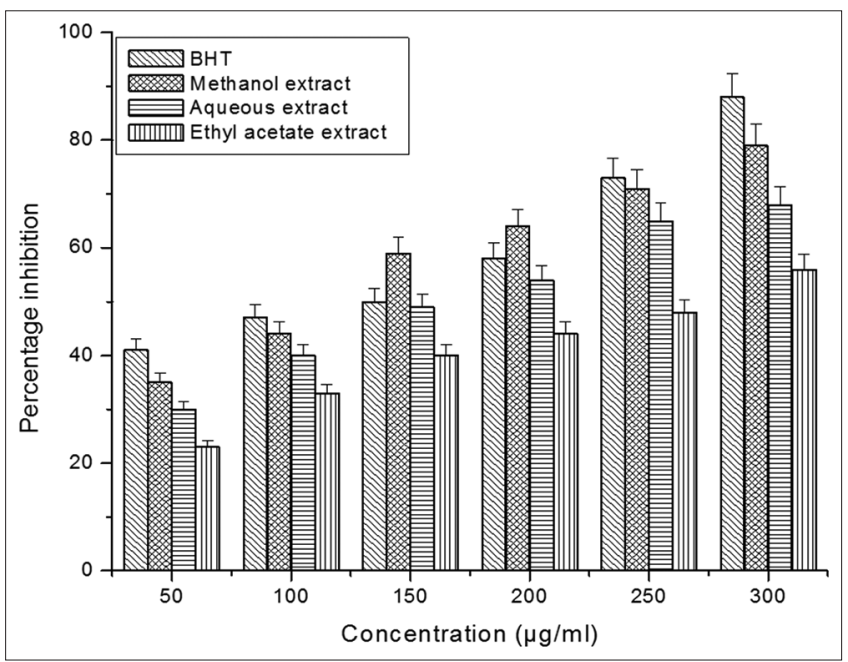

Fig. 4: The effect of different extracts of Taxus wallichiana and known antioxidant butylated hydroxytoluene on lipid peroxidation levels measured at $532 \mathrm{~nm}$, with each result representing mean \pm standard deviation of 3 separate experiments

observed due to T. wallichiana extracts (Fig. 5). All the extracts exhibited significant activity, above $70 \%$ in a concentration dependent manner with maximal inhibition of $89 \%$ with methanol extract, $78 \%$ with aqueous extract, and $72 \%$ with ethyl acetate extract at $300 \mu \mathrm{g} / \mathrm{ml}$ with 
IC50 value of $82.34 \mu \mathrm{g} / \mathrm{ml}$ (methanol), $175.33 \mu \mathrm{g} / \mathrm{ml}$ (aqueous), and $199.05 \mu \mathrm{g} / \mathrm{ml}$ with ethyl acetate extract (Table 2). BHT used as standard inhibits the hydroxyl radical up to $96 \%$ with the same concentration.

Hepatoprotective potential and histopathological study

$\mathrm{CCl}_{4}$ administration resulted significant elevation of ALT, AST, and lactate dehydrogenase (LDH) (Table 3), and this probably occurs through induction of hepatic damage in control animals as compared to normal animals [27], while standard drug Vitamin C treatment reduced ALT, AST, and LDH concentration in animals of standard group and those were almost equivalent to normal. In the present study, $\mathrm{CCl}_{4}$ elevated levels of ALT, AST, and LDH in positive control animals which may be due to reduced function of liver due to toxicity. Treatment with methanolic extract of $T$. wallichiana significantly reduced concentration of above serum parameters in animals of therapeutic groups which could be due to protection given by $T$. wallichiana methanolic extract.

Histopathological study of the liver from different groups of rats corroborated the hepatoprotective efficacy of T. wallichiana. Breakage of carbon tetrachloride leads to the formation of free radicals, resulting in steatosis, centrilobular necrosis, and cytoplasmic vacuolation as observed in toxic control group. However, these pathological changes were moderately prevented by methanolic extract groups and standard group. Normal hepatic integrity similar to normal group was seen in the Vitamin C-treated group. While groups treated with methanolic extract at 100 and $300 \mathrm{mg} / \mathrm{kg}$ body weight showed almost normal hepatic architecture with less infiltration of fat and absence of necrosis (Fig. 6). It is evident that the T. wallichiana caused regeneration of liver parenchyma cells and treated hepatic cell damage due to $\mathrm{CCl}_{4}$ toxicity.

\section{DISCUSSION}

Plant-derived medications are used as the basis of many of the modern pharmaceuticals that we use today for the treatment of our various ailments [28]. T. wallichiana is one of the medicinally important plants used ethnopharmacologically for the treatment of various disorders. The curative benefit of medicinal plants is usually attributed to their antioxidant properties. Antioxidants are considered body's first line of defense oxidative stress induced damage ingestion of dietary antioxidants has been implicated in suppressing the free radical production or scavenging free radicals and may thus prevent harmful effect of these free radicals. Several phytochemicals such as tannins, phenols, and flavanols are considered as good antioxidants. Phytochemical analysis exhibited that $T$. wallichiana constitute antioxidant compounds such as flavonoids, tannins, and phenols and showed considerable $\mathrm{IC}_{50}$ values in different extracts help in scavenging the free radicals and protect us from various diseases. They exercise their action either by cleansing the ROS or protecting the antioxidant machinery of the cell [29]. In the present study, in vitro antioxidant and hepatoprotective activity of different extracts of T. wallichiana were tested using $\mathrm{DPPH}, \mathrm{OH}$, superoxide radical scavenging, and LPO assays. DPPH is a stable free radical at room temperature and accepts an electron or hydrogen radical to turn into stable diamagnetic molecule [30]. The DPPH test is extensively used method to assess the free radical scavenging effect of plant extracts. This method is based on the reduction of DPPH solution in the presence of antioxidant resulting in the formation of non-radical DPPH-H by the reaction. The stable DPPH was reduced by all the extracts and thus changing the color from purple to yellow to varying degree depending on the presence of antioxidant compounds. The degree of discoloration indicates the scavenging potential of the extract. In the present study, among all the extracts tested, the highest capacity to neutralize DPPH radicals was found for the methanolic extracts. Similar results were obtained by Beknal et al. while evaluating the antioxidant potential of Drynaria quercifolia rhizome [31].

Phenolics are range of different secondary metabolites and have the great ability of sequestering of free radicals or chelation of metal ions.

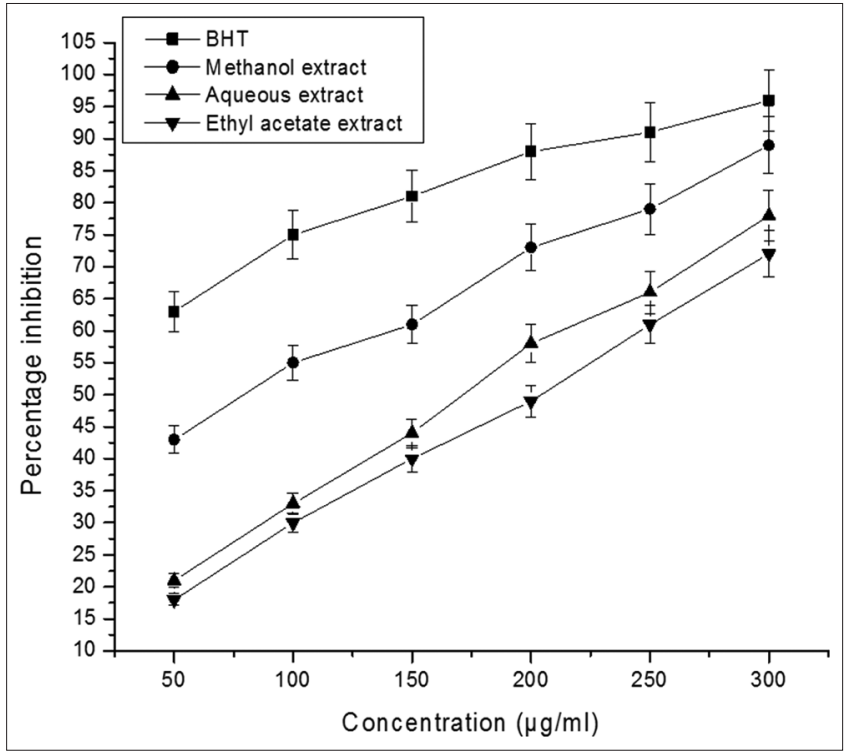

Fig. 5: The effect of different extracts of Taxus wallichiana and known antioxidant butylated hydroxytoluene on the hydroxyl activity, measured at $532 \mathrm{~nm}$, with each result representing mean \pm standard deviation of 3 separate experiments

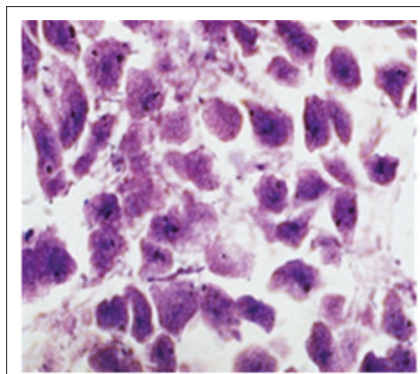

Normal group

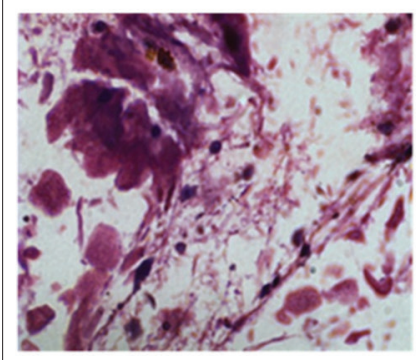

$\mathrm{CCL}_{4}$ treated group (control)

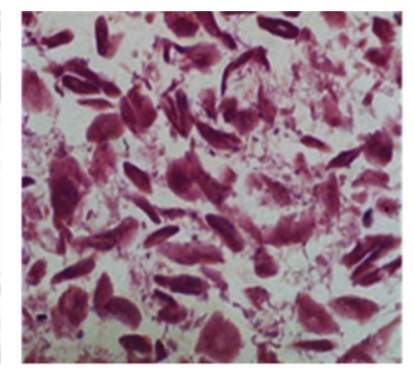

Vitamin C treated group (standard)

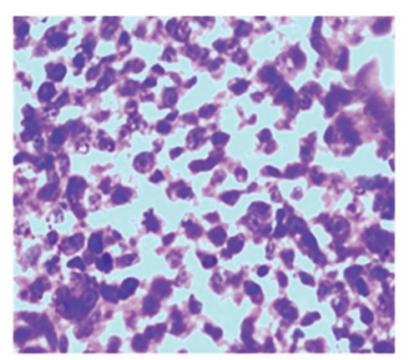

Methanol extract treated group at $100 \mathrm{mg} / \mathrm{kg}$ body weight

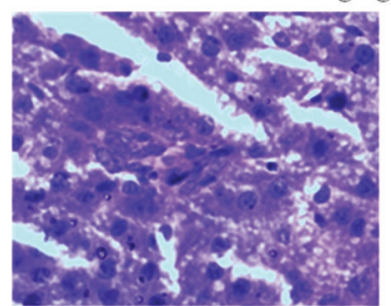

Methanol extract treated group at $300 \mathrm{mg} / \mathrm{kg}$ body weight

Fig. 6: Histopathological study confirming the hepatoprotective action of methanolic extract $(100 \mathrm{mg} / \mathrm{kg}$ body weight and $300 \mathrm{mg} / \mathrm{kg}$ body weight) of Taxus wallichiana in CCl4 induced hepatotoxic rats ( $n=6$ in each group) when compared to normal, control, and standard 
It has been reported that the antioxidant activity of phenol is chiefly due to its redox properties, hydrogen donors, and singlet oxygen quenchers [32]. Hence, TPC was estimated through modified FolinCiocalteu method.

In reducing power assay, the readiness to donate electron by a bioactive compound is index of its reducing power and antioxidant activity [33]. Antioxidants cause the reduction of $\mathrm{Fe}^{3+}$ into $\mathrm{Fe}^{2+}$, then changing the solution into various shades from green to blue, depending on the reducing power of compounds $[34,35]$. The ferric reducing power activity of different extracts of T. wallichiana seems to be due to the presence of polyphenols which correlate to its TPC and phytochemical screening. Based on the measured absorbance, the concentration of phenolics was expressed as milligram per GAE. Methanolic extract with TPC $(149.24 \pm 2.70 \mathrm{mg} / \mathrm{GAE})$ increases the reducing power capacity of T. wallichiana in a dose-dependent manner. Hence, methanolic extract of T. wallichiana possibly acts as electron donors and could react with free radicals to alter them into more stable products and then cease the free radical chain reactions. Our findings are in tune with the results observed by Irshad et al. and were studying the antioxidant activity of Cassia fistula extracts [36].

Superoxide anion $\mathrm{CO}_{2}^{-\mathrm{J}}$ is one of the most important agents from free radicals. It acts as a precursor of more ROS such as single oxygen and hydroxyl radicals that have the capacity of reacting with biological macromolecules and thereby incurring tissue damage, and also plays a pivotal role in peroxidation of lipids [37]. Methanol extract with $\mathrm{IC}_{50}$ value of $170.30 \pm 2.27 \mu \mathrm{g} / \mathrm{ml}$ showed strong superoxide radical scavenging activity than aqueous and ethyl acetate extract.

In the present study, we measured the potential of T. wallichiana extracts to inhibit LPO in rat liver microsomes induced by the $\mathrm{Fe}^{2+}$ / ascorbate system. Different extracts protected against LPO induced by $\mathrm{Fe}^{2+}$ considerably reduced MDA content in a concentration dependent manner. Methanol extract had the greatest inhibiting activity (79.00\%), with the lowest IC $_{50}$ value $126.09 \mu \mathrm{g} / \mathrm{ml}$. similar results were reported by Gul et al. while studying the antioxidant and anti-proliferative activities of Abrus precatorius leaf extract [38].

Hydroxyl radical is produced by a mixture of $\mathrm{Fe}^{3+}, \mathrm{H}_{2} \mathrm{O}_{2}$, and ascorbic acid and is assessed by monitoring the degraded fragments of deoxyribose, through malondialdehyde (MDA) formation and DNA strand breaks in calf thymus DNA [39]. The plant extracts or drugs scavenging the hydroxyl radical, probably by either sequestering the radical or may chelate the $\mathrm{Fe}^{2+}$ ion, hence halting the Fenton's reaction. Plant extracts endowed with polyphenols are reported to quench oxygen-derived free radicals by lending a hydrogen atom or an electron to the free radical or by their chelating ability of the aromatic ring [40].

In our study, we tested different extracts of T. wallichiana and it was observed that extracts exhibit a dose-dependent hydroxyl radical scavenging activity and prevents the Calf thymus DNA damage. Our results are in tune with the results reported by Sundararajan and Koduru, while studying the antioxidant activity of Limnophila heterophylla [41]. Furthermore, similar results were obtained by Saiah et al. while analyzing the antioxidant activity of six Algerian medicinal plants [42].

The results obtained from estimation of biochemical parameters suggest that T. wallichiana at the doses $100 \mathrm{mg} / \mathrm{kg}$ and $300 \mathrm{mg} / \mathrm{kg}$ of methanolic extract possess significant hepatoprotective property in $\mathrm{CCl}_{4}$ induced liver toxicity in rat model. This study indicated the doseeffect relationship of T. wallichiana extract. The histopathological studies supported the results of biochemical tests treated with $100 \mathrm{mg}$ and $300 \mathrm{mg} / \mathrm{kg}$ doses of methanolic extract of T. wallichiana protecting the cellular integrity and architecture of the liver. The histopathological studies strongly suggest that $100 \mathrm{mg}$ and $300 \mathrm{mg} / \mathrm{kg}$ doses of methanolic extract of T. wallichiana protect the cellular integrity and architecture of the liver. Similar results were obtained by Singh et al. while examining the antioxidant, and hepatoprotective activities of Amorphophallus campanulatus [43].
The DPPH, superoxide radical, hydrogen peroxide, hydroxyl radical, and LPO assays gave corresponding results for the antioxidant activity measured in methanol, aqueous, and ethyl acetate us extracts of T. wallichiana. These results refer to a correlation among different antioxidant assays, especially when the assays are compared with the $\mathrm{DPPH}$, which is one of the most extensively used method for screening the antioxidant activity of plant extracts.

\section{CONCLUSIONS}

Overall, it could be concluded that T. wallichiana possesses a potent antioxidant activity. In our study, we also observed that the extracts have a very tangible role in protecting liver from free radical damage. The preliminary chemical examination of different extracts of T. wallichiana has shown the presence of a number of polyphenols which may be responsible for the hepatoprotective activity. Additional studies are needed to characterize the active compounds and to clarify the in vivo potential of this plant.

\section{ACKNOWLEDGMENTS}

Authors are thankful to faculty of the Department of Biochemistry, University of Kashmir for their timely help and insightful ideas. We are also grateful to curator, COPT, University of Kashmir.

\section{AUTHOR'S CONTRIBUTION}

All the authors have contributed equally.

\section{CONFLICTS OF INTEREST}

The authors have no personal or financial conflicts of interest associated with this work.

\section{REFERENCES}

1. Khan M, Verma SC, Srivastava SK, Shawl AS, Syamsundar KV, Khanuja SP, et al. Essential oil composition of Taxus wallichiana Zucc. from the northern Himalayan region of India. Flavour Frag J 2006;21:772-5.

2. Nisar M, Khan I, Simjee SU, Gilani AH, Perveen H. Anticonvulsant, analgesic and antipyretic activities of Taxus wallichiana Zucc. J Ethnopharmacol 2008;116:490-4

3. Purohit A, Maikhuri RK, Rao KS, Nautiyal S. Impact of bark removal on survival of Taxus baccata L. (Himalayan yew) in Nanda Devi biosphere reserve, Garwhal Himalaya, India. Curr Sci 2001;81:586-90.

4. Khan I, Nisar M, Shah MR, Shah H, Gilani SN, Gul F, et al. Antiinflammatory activities of Taxus abietane A isolated from Taxus wallichiana Zucc. Fitoterapia 2011;82:1003-7.

5. Qayum M, Nisar M, Shah MR, Adhikari A, Kaleem WA, Khan I, et al. Analgesic and antiinflammatory activities of taxoids from Taxus wallichiana Zucc. Phytother Res 2012;26:552-6.

6. Nisar M, Khan I, Ahmad B, Ali I, Ahmad W, Choudhary MI. Antifungal and antibacterial activities of Taxus wallichiana Zucc. J Enzyme Inhib Med Chem 2008:23:256-60.

7. Chattopadhyay SK, Pal A, Maulik PR, Kaur T, Garg A, Khanuja SP. Taxoid from the needles of the himalayan yew Taxus wallichiana with cytotoxic and immunomodulatory activities. Bioorg Med Chem Lett 2006;16:2446-49.

8. Gonzalez J. Medicinal plants in Colombia. J Ethnopharmacol $1980 ; 2: 43-7$

9. Sies H. Role of reactive oxygen species in biological processes. Wiener Klin Wochenschr 1991;69:965-8.

10. Halliwell B. Role of free radicals in the neurodegenerative diseases: Therapeutic implications for antioxidant treatment. Drugs Aging 2001:18:685-716.

11. Aviram M. Review of human studies on oxidative damage and antioxidant protection related to cardiovascular diseases. Free Radic Res 2000;33:S85-97.

12. Klaunig JE, Kamendulis LM. The role of oxidative stress in carcinogenesis. Annu Rev Pharmacol Toxicol 2004;44:239-67.

13. Stocker R, Keaney JF. Role of oxidative modifications in atherosclerosis. Physiol Rev 2004;84:1381-478.

14. Chandan BK, Saxena AK, Shukla S, Sharma N, Gupta DK, Singh K. Hepatoprotective activity of wood Fordia fruticosa Kurz flowers 
against carbon tetrachloride induced hepatotoxicity. J Ethnopharmacol 2008;119:218-24.

15. Feijoo M, Túnez I, Ruiz A, Tasset I, Munoz E, Collantes E. Oxidative stress biomarkers as indicator of chronic inflammatory joint diseases stage. Reumatol Clin 2010;6:91-4.

16. Basu S. Carbon Tetrachloride-Induced Hepatotoxicity: A Classic Model of Lipid Peroxidation and Oxidative Stress. In: Basu S, Wiklund L, editors. Studies on Experimental Models. Totowa: Humana Press; 2011.

17. Robins V, Kumar SL, Mitchell F. The Liver, Gallbladder, and Biliary Tract: Basic Pathology. $8^{\text {th }}$ ed. Philadelphia, PA: W.B. Saunder Co.; 2007.

18. Masuda Y. Learning toxicology from carbon tetrachloride induced hepatotoxicity. Yakugaku Zasshi 2006;126:885-99.

19. Taniguchi M, Takeuchi T, Nakatsuka R, Watanabe T, Sato K. Molecular process in acute liver injury and regeneration induced by carbon tetrachloride. Life Sci 2004;75:1539-49.

20. McDonald S, Prenzler PD, Antolovich M, Robards K. Phenolic content and antioxidant activity of olive extracts. Food Chem 2001;73:73-84.

21. Kim DO, Lee LW, Lee HJ, Lee CY. Vitamin C equivalent antioxidant capacity (VCEAC) of phenolics phytochemicals. J Agric Food Chem 2002;50:3713-7.

22. Oyaizu M. Studies on product of browning reaction prepared from glucose amine. Japan J Nutr 1986;44:307-315.

23. Halliwell B, Gutteridge JM, Aruoma OI. The deoxyribose method: a simple "test-tube" assay for determination of rate constants for reactions of hydroxyl radicals. Anal Biochem 1987;165:215-9.

24. McCord JM, Fridovich I. Superoxide dismutase: An enzymic function for erythrocuprein (hemocuprein). J Biol Chem 1969;244:6049-55.

25. Chang ST, WU JH, Wang SY, Kang PL, Yang NS, Shyur LF. Antioxidant activities of extracts from Acacia confuse bark and heartwood. J Agric Food Chem 2001;49:3420-24.

26. Patrick-Iwuanyanwu KC, Amadi U, Charles IA, Ayalogu EO. Evaluation of acute and subchronic oral toxicity study of baker cleansers bitters-a polyherbal drug on experimental rats. EXCLI 2012;11:632-40.

27. David LW, Vincent M. Biochemistry in Clinical Practice. New York: Worth Publishers; Test Indicating Hepatocellular Damage; 1985.

28. Gajalakshmi S, Vijayalakshmi S, Rajeswari DV. Phytochemical and pharmacological properties of Annona muricata: A review. Int J Pharm Pharm Sci 2012;4:3-6.

29. Umamaheswari M, Chatterjee TK. In vitro antioxidant activities of the fractions of Coccinia grandis L leaf extract. Afr J Trad Compl Alt Med
2008;5:61-73.

30. Macwan CP, Patel MA. Antioxidant potential of dried root powder of Capparis zeylanica linn. Int J Pharm Pharm Sci 2010;2:58-60.

31. Beknal AK, Korwar PG, Halkai MA, Kulkarni U, Patil BS, Soodam SR. Phytochemical investigation and antioxidant activity study of Drynaria quercifolia linn rhizome. Int J Curr Pharm Res 2010;2:36-9.

32. Rice-Evans CA, Miller NJ, Bollwell PG, Bramley PM, Pridham JB. The relative antioxidant activities of plant derived polyphenolic flavonoids. Free Radic Res 1995;22:375-83.

33. Siddhuraju P, Mohan PS, Becker K. Studies on the antioxidant activity of Indian Laburnum (Cassia fistula L.): A preliminary assessment of crude extracts from stem bark, leaves, flowers and fruit pulp. J Agric Food Chem 2002;79:61-7.

34. Jayanthi P, Lalitha P. Reducing power of the solvent extracts of Eichhornia crassipes (mart.) solms. Int J Pharm Pharm Sci 2011;3:126-8.

35. Ferreira IC, Baptista P, Vilas-Boas M, Barros L. Free radical scavenging capacity and reducing power of wild edible mushrooms from northeast Portugal: Individual cap and stripe activity. Food Chem 2007;100:1511-6.

36. Irshad MD, Zafaryab MD, Rizvi MM. Comparative analysis of the antioxidant activity of Cassia fistula extracts. Int $\mathrm{J}$ Med Chem 2012;2:1-6.

37. Pulido R, Bravo L, Saura-Calixto F. Antioxidant activity of dietary polyphenols as determined by a modified ferric reducing/antioxidant power assay. J Agric Food Chem 2000;48:3396-402.

38. Gul MZ, Ahmad F, Kondapi AK, Qureshi IA, Ghazi IA. Antioxidant and antiproliferative activities of Abrus precatorius leaf extracts-an in vitro study. BMC Compl Alt Med 2013;13:1-12.

39. Rathee JS, Hassarajani SA, Chattopadhyay A. Antioxidant activity of Mammea longifolia bud extracts. Food Chem 2006;99:436-43.

40. Becana M, Klucas RV. Transition metals in legume root nodules; Irondependent free radical production increases during nodule senescence. PNAS 1992;89:8958-62.

41. Sundararajan R, Koduru R. In vitro antioxidant activity on roots of Limnophila heterophylla. Free Radic Antioxid 2016;6:178-85.

42. Saiaha H, Allemb R, zohra-el-kebira F. Antioxidant and antibacterial activities of six Algerian medicinal plants. Int J Pharm Pharm Sci 2016;8:367-74.

43. Singh P, Singh RL, Kakkar P. Antioxidant, DNA damage protective and hepatoprotective activities of Amorphophallus campanulatus. Int J Pharm Pharm Sci 2016;8:330-8. 